\title{
Ayurvedic concept of addiction, withdrawal \& its solution
}

\author{
Sharad M. Porte \\ Lecturer, P.G. Dept. of Agad Tantra (Ayurvedic Toxicology), National Institute of Ayurveda, Jaipur (India) 302002. \\ E-mail: portesmdr@gmail.com
}

\begin{abstract}
Background: Drug addiction is defined as the continued compulsive use of drugs despite adverse health or social consequences and Withdrawal is the physical and/or psychotic disorders developed by drug addicts after they stop taking drugs or reduce their dose. Drug addiction is very common in our society and it crosses all races, ethnic groups, and social classes.

Methods: This research article is basis on personal experience \& thorough review of Ayurvedic Text. The main Ayurvedic Text used in this study are Kashyapa, Charak, Sushrut, \& Vangsen Samhita and available commentaries of those. Modern Texts \& Article published in Journals also has referred to collect information on the relevant topics.

Results: Ayurveda has mentioned the Alcoholism \& Alcohol withdrawal under the heading of 'Madatyaya \& Panapakrama' respectively. Ayurveda has mentioned the 'Satmikarana' a procedure of adaptation by gradual \& logical decreasing the dose of addicted substance, which has already become a wholesome. Madya (Alcohol) in Madya is a unique principle which will be used in the treatment of addiction by decreasing the cellular level of drugs slowly \& safe the patient from the withdrawal effect. The Padansha Krama which is described in the Ayurveda to reject the un-suitable substance will be necessary \& useful to tapper up the addicted drugs. Psychological counselling, Recreational \& Motivational Enhancement Therapy can be also used effectively for the rehabilitation the addicted patient, which is also described in Ayurveda.
\end{abstract}

Conclusions: Thus Ayurveda have ultimate \& effective solution in the Management \& Rehabilitation of Drug Addiction.

Keywords: Addiction, De-Addiction, Withdrawal Syndrome, Ayurvedic Solution.

\section{Introduction}

Addiction is a complex disorder characterized by compulsive drug use. Individuals make choices to begin using drugs. Some people begin using drugs to relieve a medical condition and then continue to use the drugs after the medical need is over. Other people begin taking drugs to feel pleasure, to escape the pressures of life, or to alter their view of reality. Withdrawal is the physical and/or psychotic disorders developed by drug addicts after they stop taking drugs or reduce their dose. There are dozens of illegal addictive substances, such as cocaine, methamphetamine and heroin but many others are not only legal, they are easily accessible in almost every home. Caffeine, aerosols, alcohol, nicotine and prescription medicines can all be addictive. Despite increased attention to drug demand reduction in recent years, drug use continues to take a heavy toll. Globally, some 210 million people use illicit drugs each year, and almost 200,000 of them die from drugs. There continues to be an enormous unmet need for drug use prevention, treatment, care and support, particularly in developing countries (Chawla Sandeep 2011). India has a large unmet need for deaddiction services (Ray R.et.al, 2004).

In India, The drug dependence treatment sector is still developing and undergoing refinement. The treatment services for substance use disorder in India are delivered by three major players. The first major player is the Non-Governmental Organisation (NGO) sector. There are around 430 drug dependence treatment centres throughout the country, which are being run by NGOs, supported

by the Ministry of Social Justice and Empowerment, Government of India. Another major group is the private sector; many doctors including a large number of psychiatrists are providing services to people for substance use related problems. The thirds major group is Government De-addiction Centre. The Ministry of Health and Family Welfare, Government of India, has established about 122 drug dependence treatment centres throughout the length and breadth of the country (Tripathi B. M. et.al 2009). In Ayurveda though the description of Alcohol withdrawal found under the heading of 'Panapakrama' briefly, the drugs addiction, withdrawal \& it's solution of another drugs like Opium, Cannabis, Tobacco \& another chemical not found in Brihatrayi \& Laghutrayi and it is need of time to evaluate by using the concept of Ayurveda. The Satmikaran Procedure, Padansha Krama, Madya in Madya, Psychological Counselling and Music-Recreational \& Motivational Enhancement Therapy these unique concept has found only in Ayurveda to de-addict \& rehabilitate the addicted patients. But matter is scattered \& need to collect, evaluate, elaborate \& discussed on the scientific background.

\section{Methods}

This research article is basis on personal experience \& thorough review of Ayurvedic Text. The main Ayurvedic Text used in this study are Kashyapa, Charak, Sushrut, \& Vangsen Samhita and available commentaries of those. Modern Texts \& Article published in Journals also has referred to collect information on the relevant topics. 


\section{Result}

\subsection{Addiction \& withdrawal}

Addiction is Habitual psychological or physiologic dependence on a substance or practice that is beyond voluntary control. Withdrawal has many meanings, one of which is a psychological and/or physical syndrome caused by the abrupt cessation of the use of a drug in a habituated person. Withdrawal is the body's reaction to abstaining from an addictive substance of which it has become dependent and tolerant. Without the substance, physiological functions that were dependent on the substance will react because of the body's tolerance and dependence of the substance. Chemical and hormonal imbalances may arise if the substance is not introduced. Physiological and psychological stress is to be expected if the substance is not re-introduced.

\subsection{Types of addictive substance}

Stimulants- as the name implies, these drugs stimulate the user which included Amphetamine, Anorectic, Cocaine \& Pyridine Alkaloids Class. Depressants generally have the opposite effect of stimulants. Many depressant are used as sedatives or tranquilizers, terms often used as if they mean the same thing even though some experts would dispute such interchangeable usage of the terms sedative and tranquilizer, which included Barbiturate, Benzodiazepine and Opiate along with alcohol. The steroids governed by schedules of controlled substances are anabolic steroids. The steroids governed by schedules of controlled substances are anabolic steroids. Although various drugs cause hallucinations, some drugs are so notable for such an effect that they are classified as hallucinogens (Richard L. M., 2002).

\subsection{Ayurvedic concept of addiction \& withdrawal}

If the substance, whatever it may be healthy or unhealthy, safe or unsafe, good or bad will be homologues then it is called as Satmya or Oak-Satmya. Acharya Charak stated that the Satmya \& Upashaya have the same meaning. It has the three types namely superior, inferior \& medium and seven types according to six rasa \& collectively (Pandeya Gangasahaya 1997). Chakrapani explained that Satmya is Oak-Satmya which is proceeding by practices. Acharya Charak again stated about Satmya that it is adaptation of

any substance by living after continuous \& constantly ingestion (Kashinath Pandey, et al, 2005). The addicted substance, though they are unsafe \& injurious to living, become homologues (satmya) \& so body demanded to fulfils the level of those substances within cells (koshika) and when this cellular level is decreased, withdrawal signs \& symptoms will be developed. Acharya Charak has also stated that if an non-homologous (Apathya) substance has become wholesome to a person because of the habit (Auchitya) or nature of place of habitant (Desha), then sudden \& total withdrawal of this substance even it non-homologous does not gives happiness to persons (Murthy Shrikant 1999). Acharya Vagbhat also stated that sudden discontinue of unhealthy things or indulgence of healthy things gives rises to disease. (Murthy Shrikant 1994).

\subsection{Reward circuit theory}

The activation of the ventral tegmental area and the resulting flood of dopamine within the nucleus accumbens are the first steps of initial drug use that can eventually lead to the chronic and compulsive patterns that define drug abuse. Recent research with humans using the latest brain imaging technology has increased our understanding of the neurobiology underlying this important transition. Following repeated drug use that produces unnaturally high levels of dopamine within the reward system, the brain adapts by decreasing the number of receptors that dopamine specifically targets (i.e., dopamine receptors). There are several types of dopamine receptors, and all are important to healthy brain function, but the one most consistently associated with drug abuse is the dopamine receptor called D2R. Results from research using PET imaging have demonstrated significant reductions of D2R in the reward system of individuals with substance abuse problems.9 Researchers reason that the reduction in D2R following long-term drug use can eventually result in a state of anhedonia, which is characterized by a lack of enjoyment in activities that were previously enjoyable such as socializing with friends and family or engaging in healthy non-drug-related activities. These individuals may feel compelled to take drugs just to relinquish this anhedonic state and approximate normal reward system function. (Anker Justin J. 2012).

\subsection{Properties of addicted drugs as Ayurveda}

Table 1: Properties of Addicted Drugs as Ayurveda

\begin{tabular}{|c|c|c|c|c|c|}
\hline Sr. & Properties & $\begin{array}{l}\text { Alcohol } \\
\text { (Kashinath Shastri et } \\
\text { al, 1987). }\end{array}$ & $\begin{array}{l}\text { Opium } \\
\text { (Sharma P. V.1981). }\end{array}$ & $\begin{array}{l}\text { Cannabis } \\
\text { (Sharma P. V.1981). }\end{array}$ & $\begin{array}{l}\text { Tobacco } \\
\text { (Sharma P. V.1981). }\end{array}$ \\
\hline 1 & Light (Laghu) & $\checkmark$ & $\checkmark$ & $\checkmark$ & $\checkmark$ \\
\hline 2 & Dryness (Ruksha) & $\checkmark$ & $\checkmark$ & - & - \\
\hline 3 & Hot (Ushna) & $\checkmark$ & - & - & - \\
\hline 4 & Sharp (Tikshna) & $\checkmark$ & - & $\checkmark$ & $\checkmark$ \\
\hline 5 & Fine (Sukshma) & $\checkmark$ & $\checkmark$ & - & - \\
\hline 6 & Cleanness (Vishad) & $\checkmark$ & - & - & - \\
\hline 7 & Quick Absorption (Vyavayi) & $\checkmark$ & $\checkmark$ & - & $\checkmark$ \\
\hline 8 & Extensive(Vikasi) & $\checkmark$ & $\checkmark$ & - & $\checkmark$ \\
\hline 9 & Quick Acting (Ashukari) & $\checkmark$ & - & - & \\
\hline 10 & Taste (Rasa) & Sour (Amla) & $\begin{array}{l}\text { Bitter (Tikta), Astrin- } \\
\text { gent (Kashaya) }\end{array}$ & Bitter (Tikta) & $\begin{array}{l}\text { Bitter (Tikta), } \\
\text { Pungent (Katu) }\end{array}$ \\
\hline 11 & Potency (virya) & - & Hot (Ushna) & Hot (Ushna) & Hot (Ushna) \\
\hline 12 & Digestion Conversion (Vipak) & - & Pungent (Katu) & Pungent (Katu) & Pungent (Katu) \\
\hline 13 & Natural power (Prabhav) & - & Intoxicating (Madaka) & Intoxicating (Madaka) & Intoxicating (Madaka) \\
\hline 14 & Kapha-Vatahar & $\checkmark$ & $\checkmark$ & $\checkmark$ & $\checkmark$ \\
\hline 15 & Pitakar & $\checkmark$ & $\checkmark$ & $\checkmark$ & $\checkmark$ \\
\hline
\end{tabular}

In Brihatrayi Ayurvedic properties of Alcohol has been found, but properties of Opium, Cannabis \& Tobacco has not found and it has mentioned in Laghutrayi along with Alcohol. The entire properties of Alcohol are similar to properties of Poison except Taste (Rasa), the properties of Opium; Cannabis \& Tobacco are also similar to some properties of Poison, except some. The above drugs have Light (Laghu) guna \& Hot (Ushna) potency, Kapha-
Vatahar and Pitakar, while Quick Absorption (Vyavayi) \& Quick Acting (Ashukari) are not found in Cannabis. 
Table 2: Clinical Feature of Withdrawal from Addiction

\begin{tabular}{|c|c|c|c|c|c|}
\hline Sr. & Clinical Feature & $\begin{array}{l}\text { Alcohol } \\
\text { (Sullivan John T. et al., } \\
\text { 1989). }\end{array}$ & $\begin{array}{l}\text { Opium } \\
\text { (Wesson DR; Ling W } \\
\text { 2003). }\end{array}$ & $\begin{array}{l}\text { Cannabis } \\
\text { (Budney Alan J. et } \\
\text { al.2004). }\end{array}$ & $\begin{array}{l}\text { Tobacco (Robert West et al, } \\
\text { 2006). }\end{array}$ \\
\hline 1 & Nausea \& Vomiting & $\checkmark$ & $\checkmark$ & $\checkmark$ & - \\
\hline 2 & Tremor & $\checkmark$ & $\checkmark$ & - & - \\
\hline 3 & Paroxysmal Sweats & $\checkmark$ & $\checkmark$ & - & - \\
\hline 4 & Anxiety & $\checkmark$ & $\checkmark$ & $\checkmark$ & $\checkmark$ \\
\hline 5 & Agitation & $\checkmark$ & $\checkmark$ & $\checkmark$ & $\checkmark$ \\
\hline 6 & $\begin{array}{l}\text { Tactile, Auditory \& Visual Dis- } \\
\text { turbances }\end{array}$ & $\checkmark$ & - & - & - \\
\hline 7 & Headache & Fullness & - & $\checkmark$ & - \\
\hline 8 & $\begin{array}{l}\text { Orientation \& Clouding of Sen- } \\
\text { sorial }\end{array}$ & $\checkmark$ & - & - & - \\
\hline 9 & Tachycardia & - & Resting & - & - \\
\hline 10 & Restlessness & - & $\checkmark$ & $\checkmark$ & $\checkmark$ \\
\hline 11 & Yawing & - & $\checkmark$ & - & - \\
\hline 12 & Dilated Pupil & - & $\checkmark$ & - & - \\
\hline 13 & Bones \& Joints aches & - & $\checkmark$ & - & - \\
\hline 14 & Gooseflesh Skin & - & $\checkmark$ & - & - \\
\hline 15 & Running Nose \& Tearing & - & $\checkmark$ & - & - \\
\hline 16 & Loss of Appetite & - & - & $\checkmark$ & - \\
\hline 17 & Hunger feeling & - & - & $\checkmark$ & $\checkmark$ \\
\hline 18 & Feeling of Unreality & - & - & $\checkmark$ & \\
\hline 19 & Mood Swings & - & - & $\checkmark$ & Depression \\
\hline 20 & Racing Thought & - & - & $\checkmark$ & - \\
\hline 21 & Fear & - & - & $\checkmark$ & - \\
\hline 22 & Drowsiness & - & - & $\checkmark$ & - \\
\hline 23 & Sleep Difficulties & - & - & $\checkmark$ & $\checkmark$ \\
\hline 24 & Poor Concentration & - & - & - & $\checkmark$ \\
\hline
\end{tabular}

\subsection{Clinical feature of withdrawal from addiction}

As the nature \& action of addicted drugs varies drugs to drugs, the clinical feature of drugs withdrawal varies some exception. Anxiety is the most common feature of withdrawal which found in all drugs abuse. Depression is also seen in the maximum withdrawal states of Addiction except Alcohol \& Opium. Patients will be found agitate or irritate frequently after sudden withdrawal of Drugs Addiction. Difficulty in sleep is associated with withdrawal most will be found of the time. Gastro-intestinal up sate, Tremor, Sweating, lack of concentration, restlessness these are also feature found commonly in most of the drugs withdrawal. Deliriums, Hallucination, Seizures and Psychosis may be found occasionally.

\subsection{Trividha parikshana of withdrawal patients}

Visual observation (Darshan) - In this method, the person is totally assessed by the physician and notes the enlarged or shirked body parts, colour, and shape of the body, dryness or excessive wetness. Tremor \& Excessive Sweating will be noted in Alcohol \& Opium Withdrawal, while dilated pupils, gooseflesh skin, running nose \& tearing found only in opium.

Tactile perception (Sparsha) - In this method, the physician examines a person by inspection and palpation. Resting Tachycardia will be found in Opium. Bones \& Joints aches will be found in Opium.

Questioning (Prashna) - Interrogation is an important aspects of Severity of Drugs Addition.

1) How often do you have a drink/ smoke/ingest the drug?

2) How many drinks/smoke/ingest the drug do you have on a typical day when you are taking?

3) How often do you have six or more drinks/smoke/ingest the drug on one occasion?

4) How often during the last year have you found that you were not able to stop drinks/smoke/ingest the drug once you had started?

5) How often during the last year have you failed to do what was normally expected from you because of drinks/smoke/ingest the drug?

6) How often during the last year have you needed first drinks/smoke/ingest the drug in the morning to get yourself going after a heavy drugs session?
7) How often during the last year have you had a feeling of guilt or remorse after drinks/smoke/ingest the drug?

8) How often during the last year have you been unable to remember what happened the night before because you had been drinks/smoke/ingest the drug?

9) Have you or someone else been injured as a result of your drinks/smoke/ingest the drug?

10) Has a relative or friend or a doctor or other health worker, been concerned about your drinks/smoke/ingest the drug or suggested you cut down?

\subsection{Ayurvedic pathophysiology in withdrawal}

The intake of drugs leads to the aggravation of one of more doshas (body constituents) like Vata, Pita and Kapha. In drugs addiction vitiation of Vata causes headache, insomnia, vivid dreams, hallucinations, anxiety, depression, restlessness, constipation \& tremor and vitiation Pita causes gastric up set, excessive sweating, giddiness, aggression \& violence and vitiation of Kapha cause excessive sleep, lethargy, heaviness in the body, nausea \& vomiting while vititation of Tridosha causes combination of the above clinical feature. In general Vata predominant Tridoshaj pathology will be found in physiological dependence \& withdrawal. Raja dosha amongst the Manasa (Mental) dosha will be found for psychological dependence.

\subsection{Ayurvedic solution of addiction}

Acharya Charak stated that the disease which produce due to taking of Alcohol in over-dose or less dose, suppressed by taking the same Alcohol in Medicinal doses (Kashinath Shastri et al, 1987). Chakrapani in his commentary has explained that alcohol having nutrients \& prepared from health promoting material will be settle down the alcohol addiction if given therapeutic doses. This principle of Madya in Madya will be applied during de-addiction of other addicted drugs by using the parallel therapeutic agent instead. But this therapeutics agent also need to tapper up by proper manner, otherwise it will be addicted. Hence Acharya Charak suggested a Padanshik Krama means addicted drugs should be alienated from habitual malpractice gradually \& adopted good practice similar way, because demerits given up gradually \& merits adopted in the similar way prevented \& unshakable respectively. In the first phase, alienation $\&$ adoption should be limited 
to the quarter portion. The second phase should be on the next day $\&$ succeeding at the interval of two \& three days respectively and then whole part of suitable (Kashinath Pandey et al, 2005).

Acharya Vagbhat has also mentioned the Padansik Kram \& stated that unhealthy things which have become accustomed should be discontinued by quarter \& quarter gradually and healthy thing should be also adopted gradually with the interval of $1^{\text {st }}, 2^{\text {nd }} \& 3^{\text {rd }}$ day (Murthy Shrikant 1994). Acharya Vansen stated that Signs, Symptoms \& Complication of Alcoholism should be remaining till seven or eight days after withdrawn. The similar principle will be applied in addiction withdrawal of other drugs also. So there is need to maintain the patient of withdrawal till 7 to 8 day in observation (Rai Rajiv Kumar, 1983).

\subsection{Management of addiction \& withdrawal as per Ayurveda}

Table 3: Management of Addiction \& Withdrawal as Per Ayurveda

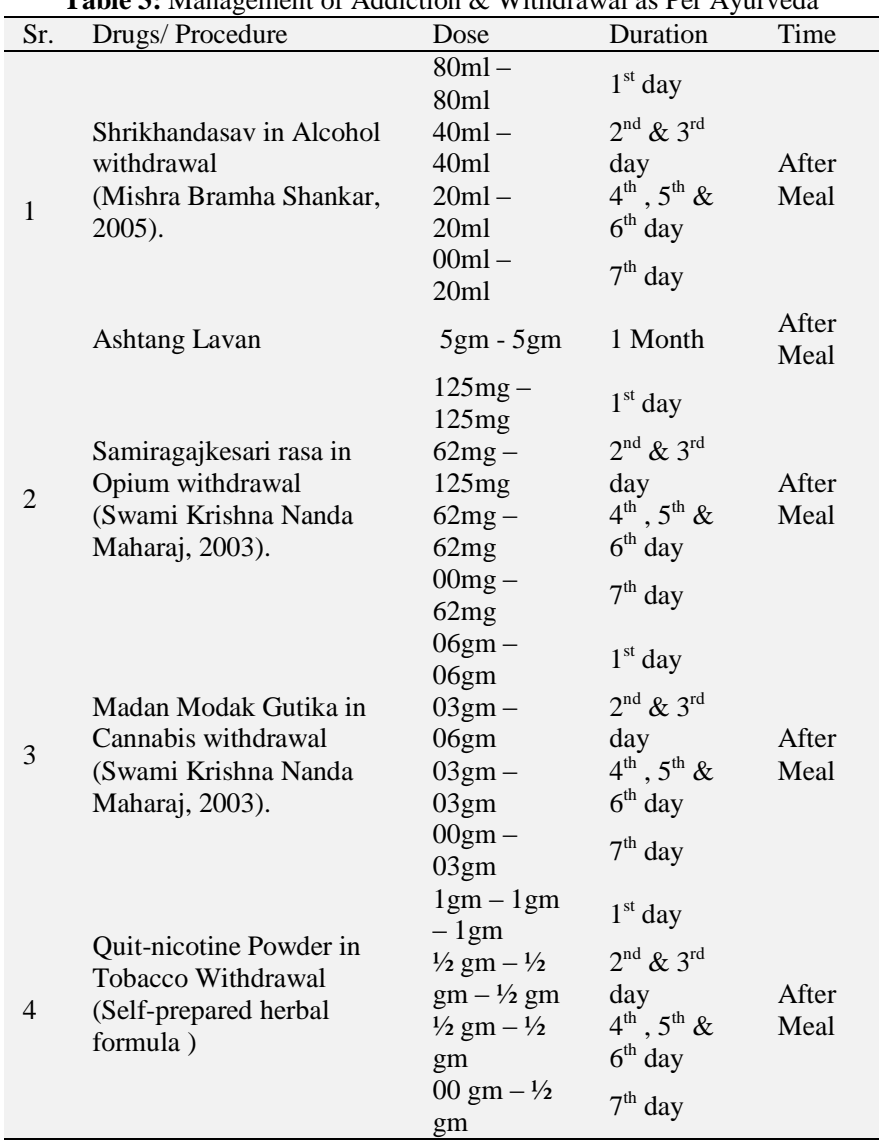

Shrikhandasav have an alcohol which will be prepared, using medicinal herbs by traditional Ayurvedic method. The chief ingredient of Samiragajkesari rasa \& Madan Modak Gutika is opium \& cannabis respectively which will be added after purification by traditional Ayurvedic method. None of the Ayurvedic Product belonging Tobacco is available in market, Quit-nicotine Powder will be prepared by using purified tobacco leaves \& Trachyspermum ammi by Ayurvedic method.
Table 4: Supportive Management of Addiction \& Withdrawal as Per Ayurveda

\begin{tabular}{|c|c|c|c|c|}
\hline Sr. & Drugs/ Procedure & Dose & Duration & Time \\
\hline 1 & $\begin{array}{l}\text { Sarpagandha Pow- } \\
\text { der }\end{array}$ & $250 \mathrm{mg}-250 \mathrm{mg}$ & 1 week & $\begin{array}{l}\text { Bed } \\
\text { Time }\end{array}$ \\
\hline 2 & Haritkyadi Yoga & $00 \mathrm{gm}-03 \mathrm{gm}$ & 1 week & $\begin{array}{l}\text { Bed } \\
\text { Time }\end{array}$ \\
\hline 3 & $\begin{array}{l}\text { Abhyang with Ma- } \\
\text { hamasha Taila }\end{array}$ & For external use & $\begin{array}{l}8^{\text {th }}-14^{\text {th }} \\
\text { day }\end{array}$ & Morning \\
\hline 4 & $\begin{array}{l}\text { Shiro Dhara with } \\
\text { Bramhi Tail }\end{array}$ & For external use & $\begin{array}{l}8^{\text {th }}-14^{\text {th }} \\
\text { day }\end{array}$ & Morning \\
\hline 5 & $\begin{array}{l}\text { Shiro Basti with } \\
\text { Bramhi Tail }\end{array}$ & For external use & $\begin{array}{l}8^{\text {th }}-14^{\text {th }} \\
\text { day }\end{array}$ & Morning \\
\hline 6 & $\begin{array}{l}\text { Shiro Abhyanga } \\
\text { with Bramhi Tail }\end{array}$ & For external use & $\begin{array}{l}8^{\text {th }}-14^{\text {th }} \\
\text { day }\end{array}$ & Morning \\
\hline 7 & $\begin{array}{l}\text { Pratham Baladi } \\
\text { Yapan Basti }\end{array}$ & $300 \mathrm{ml}$ & $\begin{array}{l}8^{\text {th }}-14^{\text {th }} \\
\text { day }\end{array}$ & Morning \\
\hline 8 & Meditation & $\begin{array}{l}\text { For improve } \\
\text { concentration }\end{array}$ & 1 Month & Morning \\
\hline 9 & $\begin{array}{l}\text { Psychological } \\
\text { Counselling }\end{array}$ & $\begin{array}{l}\text { For Mental } \\
\text { Strength }\end{array}$ & 1 Month & $\begin{array}{l}\text { Once a } \\
\text { day }\end{array}$ \\
\hline 10 & $\begin{array}{l}\text { Recreational + Mu- } \\
\text { sic Therapy }\end{array}$ & $\begin{array}{l}\text { Diversion of } \\
\text { Attentions }\end{array}$ & 1 Month & $\begin{array}{l}\text { Once a } \\
\text { day }\end{array}$ \\
\hline 11 & $\begin{array}{l}\text { Motivational En- } \\
\text { hancement Therapy }\end{array}$ & $\begin{array}{l}\text { Motivation for } \\
\text { rehabilitation }\end{array}$ & 1 Month & $\begin{array}{l}\text { Once a } \\
\text { day }\end{array}$ \\
\hline
\end{tabular}

\section{Discussion}

Ayurveda has mentioned only the Alcohol addiction \& withdrawal under the heading of Madatyaya \& Panapakram, but today the numbers of natural, semi synthetic \& synthetic drugs are found which may be addicted. The modern medicine has hypothesized the numbers of module including Reward Circuit Theory to know the process of drugs addiction. In Ayurveda this process can be understood elaborating the principle of Oak-Satmya that means the repeated use of any safe or unsafe substance including addicted material makes mutual understanding with bodily tissue by its prabhav (specific action). This phenomenon established a peculiar type of new homeostasis in the body. Here the body has depended on this addicted substance to some extent. Ayurveda has his own diagnostic method \& Trividha Parikshan including visual observation, tactile perception \& questioning which is unique and help to gives specific diagnosis \& severity of addiction. In general Vata predominant Tridoshaj pathology will be found in physiological dependence \& withdrawal and aggravation Raja dosha amongst the Manasa (Mental) dosha will be found for psychological dependence as per Ayurveda. Shrikhandasav, Sameer Gajkesari Ras \& Madan Modak Gutika will be beneficial by tapering method in Alcohol, Opium \& Cannabis Withdrawal respectively as these having same therapeutic agent. There is no such therapeutic preparation of tobacco, so Quit-Nicotine Powder self-prepared containing perched Trachyspermum ammi \& Nicotina tobacum in equal quantity for Tobacco Withdrawal in similar way. Ashtanglavan will be helped in Alcohol withdrawal only \& it relieved kaphaj feature specially (Sadalagi Shetal L. et al, 2009). Haritakyadi Yoga is a mild purgative \& will be helped to remove the aggregated Pita \& Kapha from body along with accumulated cellular toxicant (Murthy Shrikant, 2000). Rauwolfia serpentina has been used in sleep difficulty, along with drug induced mental illness, as the most of withdrawal syndrome have anxiety, depression \& insomnia as a chief clinical feature (Sharma P. V.1981). Yapan Basti (Kashinatha Shastri et al, 1987) \& Abhyanga (Atrideva Gupta, 1993) will be useful to relieve from vitiated Vata cause due to Dhatukshaya \& helped to strengthen the physical power and Shiro-Dhara, Shiro-Basti \& Shiro-Abhyang will be helped to strengthen the mental power (Atrideva Gupta, 1993). For the purposes of effective addiction recovery, a consistent and constrained period of prayer and meditation, carefully involving reasoned and planned practice and executed via an overarching long-term plan of recovery would seem essential. (Steve Sussman et al, 2011). Acharya Charak stated that Alcoholism cannot be produce without irritation of mind \& body which relieved by Happiness. Its mean that Ayurveda has known the psychological in- 
volvement \& role of psychological Counselling in the management of drugs addiction \& withdrawal (Kashinatha Shastri et al, 1987). Acharya Charak further stated that hearing of desirable, excellent stories \& excellent wording \& music relieve the Chronic Alcoholism (Kashinatha Shastri et al, 1987). So recreational therapy is an intervention tools to improve the physical, cognitive, social, behavioural, emotional, or spiritual well-being of a person with an illness or disability due to drugs addiction and will be helped to divert the attentions of patient. It is also important to remember that music is prominent in the world of drug users, so it appears to be absolutely necessary to take music into consideration in drug rehabilitation and to process also this aspect of the addiction problem. (Punkanen M. 2007). Motivational Enhancement Therapy (MET) is a systematic intervention approach for evoking change. It is based on principles of motivational psychology, and is designed to produce rapid, internally-motivated change. (William R. 1995). Thus though the drugs addiction \& its rehabilitation is not so simple, but Ayurveda have solution \& can play a major role to free the world from addiction.

\section{Conclusion}

Drugs addiction \& its withdrawal will be managed by tapper up of Ayurvedic Therapeutic Agents of same drugs in medicinal doses along Panchakarm Therapy with some extent, Meditation, Psychological Counselling, Recreational \& Music Therapy, Motivational Enhancement Therapy.

\section{Acknowledgements}

Thanks to the senior Faculty, Colleague \& PG Scholars of National Institute of Ayurveda, Jaipur India for intellectual supports.

\section{References}

[1] Sharma P. V.1981. Dravya Guna Vijnana, Chaukhambha Bharati Academy Publication Varanasi, $5^{\text {th }}$ edition, 19-24.

[2] Sharma P. V.1981. Dravya Guna Vijnana, Chaukhambha Bharati Academy Publication Varanasi, $5^{\text {th }}$ edition, 25-31.

[3] Sharma P. V.1981. Dravya Guna Vijnana, Chaukhambha Bharati Academy Publication Varanasi, $5^{\text {th }}$ edition, 36-39.

[4] Sharma P. V.1981. Dravya Guna Vijnana, Chaukhambha Bharati Academy Publication Varanasi, $5^{\text {th }}$ edition, 386-389.

[5] Rai Rajiv Kumar, 1983. Vangasen Samhita (Chikitsasara Sangraha) Madatyayadhikar 47, Prachya Prakashan Varanashi $1^{\text {st }}$ edition, 241.

[6] Kashinath Shastri et al, 1987. Charak Samhita, Chikitsasthan 24/30, Chaukhambha Orientalia Publication Varanashi $14^{\text {th }}$ edition, 671.

[7] Kashinath Shastri et al, 1987. Charak Samhita, Chikitsasthan 24/109, Chaukhambha Orientalia Publication Varanashi $14^{\text {th }}$ edition, 683.

[8] Kashinatha Shastri et al, 1987. Charaka Samhita, Chikitsa Sthan 24/157, Chaukhombha Bharati Academy Varanashi $14^{\text {th }}$ Edition, 690.

[9] Kashinatha Shastri et al, 1987. Charaka Samhita, Chikitsa Sthan 24/191-193, Chaukhombha Bharati Academy Varanashi $14^{\text {th }}$ Edition, 694.

[10]Kashinatha Shastri et al, 1987. Charaka Samhita, Siddhi Sthan 12/5, Chaukhombha Bharati Academy Varanashi $14^{\text {th }}$ Edition, 1098.

[11]Sullivan John T. et al., 1989. Assessment of Alcohol Withdrawal: the revised clinical institute withdrawal assessment for alcohol scale (CIWA-Ar). British Journal of Addiction 84, 1353-1357.

[12] Atrideva Gupta, 1993. Vagbhat, Ashtang Samgraha,Sutrasthan, 3/56 Krishnadas Academy Oriented Publication Varanashi, 29.

[13]Murthy Shrikant 1994. Ashtang Hridaya Vol.I, Sutrasthan 7/49, Krishnadas Academy Publication Varanasi $2^{\text {nd }}$ edition, 118.

[14]Murthy Shrikant 1994. Ashtang Hridaya Vol.I, Sutrasthan 7/48, Krishnadas Academy Publication Varanasi $2^{\text {nd }}$ edition, 117-118.

[15]William R. 1995. Miller 'Motivational Enhancement Therapy with Drug Abusers' Department of Psychology and Centre on Alcoholism, Substance Abuse, and Addictions (CASAA), University of New Mexico.

[16]Pandeya Gangasahaya, 1997. Charak Samhita Vimansthan 1/20. Chaukhambha Surbharati Publication Varanasi, 662.

[17]Murthy Shrikant 1999. Charak Samhita Vol.V, Chikitsasthan 30 /315, Chaukhambha Sanskrit Publication Varanasi, $1^{\text {st }}$ edition, 209-210.
[18] Murthy Shrikant, 2000. Ashtang Sangraha, Uttar Sthan 40/149, Chaukhambha Orientalia Publication Varanashi $2^{\text {nd }}$ edition, 370.

[19]Richard L. M., 2002. The encyclopedia of addictive drugs, Greenwood Press Westport, London, 11-27.

[20]Swami Krishna Nanda Maharaj, 2003.Rasa-Tantra-Sar Evm SiddhaPraypga-Sangraha Part-I, Krisha Gopal Ayurveda Bhavan Publication, $16^{\text {th }}$ edition, 463 .

[21] Swami Krishna Nanda Maharaj, 2003.Rasa-Tantra-Sar Evm SiddhaPraypga-Sangraha Part-I, Krisha Gopal Ayurveda Bhavan Publication, $16^{\text {th }}$ edition, 796-797.

[22]Wesson DR; Ling W 2003.The Clinical Opiate Withdrawal Scale (COWS). J Psychoactive Drugs; 35(2): 253-259.

[23]Budney Alan J. ET al.2004.Review of the Validity and Significance of Cannabis Withdrawal Syndrome. Am J Psychiatry; 161:1967-1977.

[24]Ray. R., Mondal A.B., Gupta K, Chatterjee A, Bajaj P 2004. The extent, pattern and trends of drug abuse in India: National survey. New Delhi: United Nations Office on Drugs and Crimes and Ministry of Social Justice and Empowerment, Government of India.

[25] Kashinath Pandey et al, 2005. Charak Samhita Sutra Sthan 7/36-38, Chaukhambha Bharati Academy Varanasi, 163-165

[26] Kashinath Pandey, et al, 2005. Charak Samhita Vimansthan 8/118, Chaukhanmbh Bharati Academy Varanasi, 780.

[27]Mishra Bramha Shankar, 2005. Bhaishajya-Ratnavali, Madatyaya Chikitsa Prakaranam 22/29-33, Chaukhambha Sanskrit Sansthan Varanashi, 18 revised editions, 504.

[28]Robert West et al, 2006. Assessing DSM-IV nicotine withdrawal symptoms: a comparison and evaluation of five different scales (MNWS). Psychopharmacology 184: 619-627.

[29]Punkanen M. 2007. 'Music Therapy as a part of drug rehabilitation' Music Therapy Today Vol.VIII (3).

[30]Sadalagi Shetal L. et al, 2009. Effect of Vamana and Ashtanga Lavana in the management of Madatyaya. AYU-VOL. 30 (4), pp. 463-468

[31] Tripathi B. M., Ambekar Atul, 2009. 'Minimum Standards of Care for the Government De-Addiction Centres' National Drug Dependence, Treatment Centre, All India Institute of Medical Sciences, New Delhi.

[32]Chawla Sandeep 'World Drug Report 2011' United Nations Office on Drugs and Crime Vienna.

[33] Steve Sussman et al, 2011. 'Drug Addiction, Love and the Higher Power'. Eval Health Prof. 34(3): 362-370.

[34]Anker Justin J. 2012. Drug Abuse, Dopamine, and the Brain's Reward System. Butler Center for Research Hazelden Foundation. 